University of Nebraska - Lincoln

DigitalCommons@University of Nebraska - Lincoln

Faculty Publications, Department of Psychology

Psychology, Department of

2000

\title{
Versatility from a Single Song: The Case of the Nightingale Wren
}

Daniel Leger

University of Nebraska-Lincoln, dleger1@unl.edu

Katherine E. Brooks

University of Nebraska-Lincoln

Judith E. O'Brien

University of Nebraska-Lincoln

Follow this and additional works at: https://digitalcommons.unl.edu/psychfacpub

Part of the Psychiatry and Psychology Commons

Leger, Daniel; Brooks, Katherine E.; and O'Brien, Judith E., "Versatility from a Single Song: The Case of the Nightingale Wren" (2000). Faculty Publications, Department of Psychology. 478.

https://digitalcommons.unl.edu/psychfacpub/478

This Article is brought to you for free and open access by the Psychology, Department of at DigitalCommons@University of Nebraska - Lincoln. It has been accepted for inclusion in Faculty Publications, Department of Psychology by an authorized administrator of DigitalCommons@University of Nebraska - Lincoln. 


\title{
Versatility from a Single Song: The Case of the Nightingale Wren
}

\author{
DANiEl W. Leger, ${ }^{1}$ Katherine E. Brooks, AND Judith E. O'Brien \\ Department of Psychology and Nebraska Behavioral Biology Group, University of Nebraska, \\ Lincoln, Nebraska 68588, USA
}

Versatility in song production of birds has drawn considerable attention since its description by Hartshorne (1956), who suggested that birds vary their vocal output to avoid habituation in listeners, especially if singing is extensive. The best-known route to song versatility involves creating permutations and combinations of song elements learned from neighbors or relatives, combined with improvisations (Nowicki et al. 1999). Birds may learn whole songs or individual song elements, which then may be arranged in novel ways.

Versatility might be achieved in other ways besides acquiring numerous song types. For example, individuals could shift the tempo of their songs by altering internote or intersong intervals. Alternatively, birds might sing the same pattern of notes but shift their frequency range. Black-capped Chickadees

\footnotetext{
${ }^{1}$ E-mail: dleger1@unl.edu
}

(Poecile atricapilla) shift the frequency of their whistled songs, which has been suggested to function as a repertoire-enlarging strategy (Horn et al. 1992). Without changing the order of song elements, shifts in tempo or frequency might change the perception of the song sufficiently to prevent habituation.

Here, we describe songs of three Nightingale Wrens (Microcerculus philomela), which are residents of tropical lowland forests from southern Mexico to central Costa Rica (AOU 1998). The song of this species has a peculiar quality that has struck some observers as being "random" because it is difficult to discern a clearly recurring pattern (Howell and Webb 1995). This distinctive song has been the primary justification for splitting M. philomela from M. marginatus, the Scaly-breasted Wren (Slud 1958; Stiles 1983, 1984).

Methods.-Recordings of Nightingale Wren songs were made by DWL at La Selva Biological Station, Costa Rica $\left(10^{\circ} 26^{\prime} \mathrm{N}, 83^{\circ} 59^{\prime} \mathrm{W}\right)$, using a Sony TCM- 


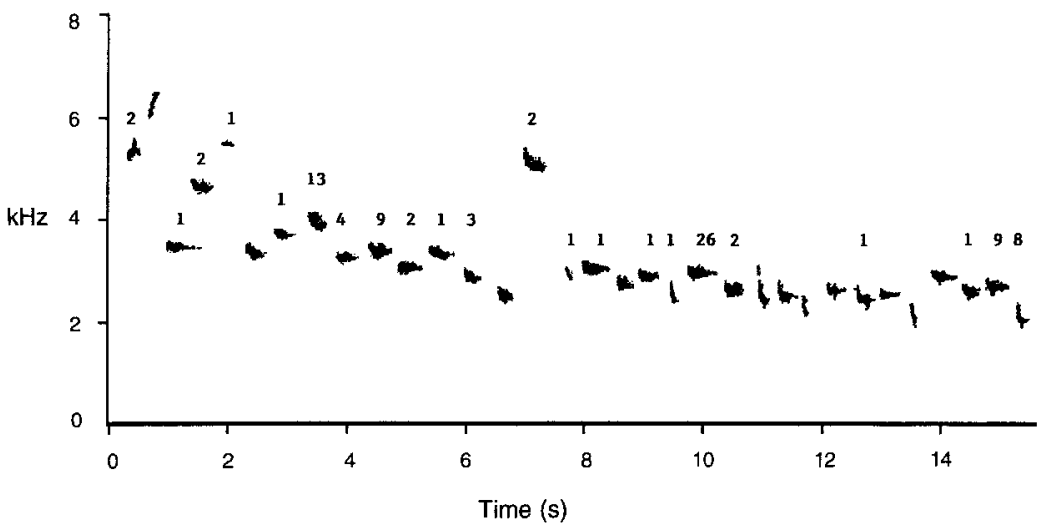

FIG. 1. Sonogram of a 33-note Nightingale Wren song recorded at La Selva Biological Station, Costa Rica. Numbers above each note indicate how many of the 1998A songs were terminated after the bird sang that note.

5000EV recorder and Sennheiser ME67/K6 microphone. One recording was made on 13 March 1998 and is $17 \mathrm{~min} 47 \mathrm{~s}$ in duration. The second recording was made on 14 March 1998 and is 3 min $48 \mathrm{~s}$ in duration. These recordings, which probably are of different individuals, are referred to below as 1998A and 1998B, respectively; copies are archived at the Borror Laboratory of Bioacoustics (numbers 25923 and 25924).

Very few archived recordings are available for $M$. philomela, but we obtained nearly all of the holdings of this species (indexed as Microcerculus marginatus) from the Library of Natural Sounds (LNS) at Cornell University. One of these recordings (LNS 28138) was made by A. van den Berg at La Selva on 29 May 1981. It is the only archived recording of sufficient duration (4.5 $\mathrm{min}$ ) to permit significant analysis. It is referred to below as 1981 .

Recordings were digitized using Canary 1.2.1 software on a Macintosh computer at a sampling rate of $44 \mathrm{kHz}$. We used Canary to extract measures of highest frequency, lowest frequency, and peak frequency of each note. The three measures proved to be highly intercorrelated, so we report only peak frequency here because it was the easiest to measure reliably. The reliability of the measure was estimated by having a second person re-measure the notes on $20 \%$ of the sonograms ( $n=455$ notes). Across all re-measured notes, the average similarity was $99.9 \%$.

Results.-Listening to a singing Nightingale Wren does not provide a clear sense of when a song begins and ends. Singing may go on more-or-less continuously for minutes with what seems to be a random output of clear, short, whistled or slurred notes given at a rate of about two notes per s. Nonetheless, our analyses revealed that each bird sang a highly stereotyped sequence of notes. The apparent randomness of the song results from stoppages of singing at almost any point, followed by a brief pause and then resumption of singing with the same notes that were given at the beginning of the sequence.

Songs began with a pair of high-frequency notes, the second of which was higher and softer than the first and was upslurred (Fig. 1). The starting pair of notes occurred whenever a pause of more than $0.5 \mathrm{~s}$ occurred during a singing bout (inter-note intervals were about $0.1 \mathrm{~s}$ ). There were 94 songs in the 1998A recording, 17 in 1998B, and 25 in 1981. Five songs in 1998A and seven in 1998B had their starting pair of notes preceded by one or two "stuttered" notes. The 1981 bird used stuttered notes 21 times, and the stutters were up to four notes long. Because stuttered notes were not given in all songs, we do not include them in the analyses that follow.

The number of notes per song was highly variable for all three individuals, but all three had maxima of either 32 or 33 notes. However, these maxima rarely were achieved because the birds stopped singing at almost any point in the song (Fig. 1). The number of notes per song averaged 17.7 \pm SD of 9.4, $23.3 \pm 10.3$, and $14.5 \pm 9.0$ for 1998A, 1998B, and 1981, respectively. We found no evidence that the longer songs consisted of repetitions of any subset of notes.

The sequential patterning of notes was highly stereotyped for each bird. For example, we took a random sample of 10 songs from 1998A that terminated after 21 notes (the most common stopping point). A correlation analysis of the peak frequencies of the notes for each pair of songs in the sample $(n=45)$ yielded a mean $r$ of $0.99(P<0.01$, all $\mathrm{df}=19)$, indicating that the frequency relationships of the notes of any song were repeated almost exactly in other songs.

Although the patterning of notes was stereotyped, birds sang their songs across a range of frequencies. For instance, the lowest peak frequency of the first note in any 1998A song was $4.85 \mathrm{kHz}$, but the first notes of the other songs were as much as $21 \%$ higher 
TABLE 1. Pearson correlations (df in parentheses) among song variables for the three recordings of Nightingale Wren songs.

\begin{tabular}{lrrr}
\hline \hline \multicolumn{1}{c}{ Variables } & $1998 \mathrm{~A}$ & $1998 \mathrm{~B}$ & 1981 \\
\hline Number of notes and frequency index of same & & & \\
song & $0.39(75)^{*}$ & $0.57(13)$ & $0.30(22)$ \\
Number of notes and following ISI & $-0.46(83)^{*}$ & $-0.65(9)$ & $-0.67(21)^{*}$ \\
Number of notes and preceding ISI & $0.17(81)$ & $0.24(11)$ & $0.07(21)$ \\
Number of notes and number of notes of next song & $-0.28(89)$ & $-0.31(12)$ & $-0.31(21)$ \\
Number of notes and frequency index of next song & $-0.54(77)^{*}$ & $-0.62(12)$ & $-0.76(21)^{*}$ \\
Frequency index and frequency index of next song & $0.43(70)^{*}$ & $-0.03(11)$ & $0.06(21)$ \\
Frequency index and preceding ISI & $0.64(74)^{*}$ & $0.91(8)^{*}$ & $0.85(21)^{*}$ \\
Frequency index and following ISI & $0.26(71)$ & $-0.25(9)$ & $0.08(21)$ \\
\hline
\end{tabular}

${ }^{*} P<0.05$ after applying Bonferroni procedure.

than that, up to a maximum of $5.9 \mathrm{kHz}$. The other notes had similar ranges. The high correlation of peak frequencies among songs means that birds shifted frequencies in almost exactly the same way.

The notes of longer songs tended to be sung in higher frequency ranges. To obtain an index of song frequency, we summed the peak frequencies of the first eight (1998A and 1998B) or seven (1981) notes, because most songs had at least that many notes. The correlation between the number of notes in a song and the song's frequency index was positive in all three recordings (Table 1 ).

We measured the intersong intervals (ISI) between 92 song pairs for the $1998 \mathrm{~A}$ recording. The mean ISI was $3.4 \pm 6.6 \mathrm{~s}$, but 36 of the ISIs lasted less than 1 $\mathrm{s}$. Several ISIs were much longer, including four that exceeded $18 \mathrm{~s}$. If these lengthy ISIs are excluded (because they were at least $2.5 z$-scores above the mean and probably were not associated with singing [Kroodsma 1977]), the mean ISI was $2.2 \mathrm{~s}$. Mean ISIs for 1998B and 1981 were 3.9 and 3.3 s, respectively.

Because of the often lengthy songs and usually brief ISIs, the percentage of time in which the bird was actually singing (i.e. the sum of song durations divided by total recording time) was very high. In our three recordings, singing time ranged from 71 to $80 \%$ of total recording time.

All three birds organized their singing bouts in predictable ways. When they sang a longer song, the following ISI was brief, and the next song tended to be shorter and had a lower frequency index. Interrelationships among these variables are summarized in Table 1.

Longer songs were followed by shorter ISIs in all three recordings (Table 1). In contrast, no significant correlation existed between song length and duration of the ISI that preceded the song (Table 1).

Lengthier songs generally were followed by shorter songs that were sung in a lower frequency. The correlations between the number of notes in successive songs were negative (although not significant), and those between the number of notes in a song and the frequency index of the next song were strongly negative (Table 1). No consistent trend occurred across recordings for the frequency indices of successive songs (Table 1). The higher the frequency index of a song the longer the pause that preceded the song; however, no systematic trend existed between the frequency index of a song and the duration of the ISI that followed it (Table 1).

The 1998A and B songs were remarkably similar. For example, we performed a correlation analysis of the peak frequencies of the four 21-note songs from 1998B with the corresponding notes of four 21-note songs drawn randomly from 1998A. The minimum $r$ for these four correlations was $0.97(P<0.01$, all df $=19$ ). Furthermore, a correlation analysis of peak frequencies of four randomly selected 32-note songs from 1998B with those of randomly selected 32-note songs from 1998A yielded a minimum $r$ of 0.95 ( $P<$ 0.01 , all $\mathrm{df}=30)$, indicating that the notes of each bird's song bore nearly identical frequency relationships to the other's song. We conclude that the two recordings came from neighboring birds that shared song types. The 1981 La Selva songs were much like those in 1998. The main difference was that the 1998 songs had a series of three notes near the beginning of the song (notes 3 to 5 or 6 to 8 in Fig. 1) that was not present in 1981.

Discussion.-The Nightingale Wren has achieved versatility in its song output despite each bird having only one song in its repertoire. This versatility is achieved by terminating the song at virtually any point in its sequence. Furthermore, songs seldom were completed. Taking all of the La Selva data together, 134 songs were initiated, but only 19 (14.2\%) were completed. Songs were terminated after as few as one note or as many as 32 (of 33) notes, and at many points in between. Because the length of a song (i.e. number of notes) and the length of the song that followed it were weakly correlated, listeners were "kept guessing" about what would come next.

Birds sometimes abort their songs before completing them, but incomplete songs have received little attention. Winter Wrens (Troglodytes troglodytes) have a complex song and often terminate their songs with- 
in or between song sections (Kroodsma 1980, Kroodsma and Momose 1991). Chaffinches (Fringilla coelebs) respond to playback of full song by singing about 10 songs that are incomplete to various degrees, after which they resume full song (Heymann and Bergmann 1988). Chaffinches sing incomplete songs when raptors fly overhead or when humans approach. Sage Sparrow (Amphispiza belli) songs begin with the same syllables but sometimes are terminated after a variable number of syllables (Rich 1983). Similar observations have been reported in White-throated Sparrows (Zonotrichia albicollis; Borror and Gunn 1965) and Harris's Sparrows (Zonotrichia querula; Shackleton et al. 1991), but neither study provided data on the commonness of incomplete songs. In Chaffinches and Sage Sparrows, however, incomplete songs are clearly the exception, whereas in Nightingale Wrens they are the rule.

Another mechanism for increasing song versatility is frequency shifting. Nightingale Wrens sing a highly stereotyped sequence of notes, but the frequency of the first note varies between 4.9 and $5.9 \mathrm{kHz}$. Frequency shifting is well studied in the whistled song of Black-capped Chickadees. The relatively simple song of this species consists of two notes at different frequencies, and chickadees maintain the frequency relationship between the two notes regardless of the absolute frequency of the first note (Hill and Lein 1987, Horn et al. 1992). Borror and Gunn (1965) also noted frequency shifting by White-throated Sparrows, and Morton and Young (1986) reported that Kentucky Warblers (Oporornis formosus) shift frequencies to approximate those of playback songs, although these authors did not describe frequency shifting in other contexts. Frequency shifting may be a method of increasing song diversity in birds that have small repertoires.

The Nightingale Wren is noteworthy, at least among wrens, for its extensive singing time. The relative amount of time spent singing ranged from about 21 to $50 \%$ in North American wrens (Kroodsma 1977), and Thryothorus sinaloa and T. felix in Mexico had values of $28 \%$ and $17 \%$, respectively (Brown and Lemon 1979). With more than $70 \%$ of the time spent singing, the Nightingale Wren clearly is exceptional in this regard, although data are lacking on other wrens.

The song bouts of Nightingale Wrens are organized in such a way that the length, frequency range, and pauses between songs are varied but nonetheless predictable. When birds sing a lengthy song, they take only a short pause afterward. However, shorter pauses tend to be followed by shorter songs that have a lower frequency range. These observations are consistent with both motivational and performance-constraint approaches to song performance (Lambrechts 1996, Podos 1997). Our observation that longer songs tend to be sung in a higher frequency range and to be followed by shorter pauses is consistent with a motivational account of song variation during a bout. However, singing long songs with a high frequency range may be a difficult task, and despite high motivation, the short pause that follows may not be sufficient for these birds to immediately repeat the performance; thus, longer and higher-frequency songs tend to be followed by shorter and lower-frequency songs (and vice versa), which may enhance the perceived variation in song output.

In conclusion, the combination of varied song lengths, frequency shifting, and short intersong intervals creates the perception of extremely long and rambling note sequences in the Nightingale Wren. This species seems to have created a versatile song performance through the use of relatively uncommon modifications of a single song.

Acknowledgments.-This work was supported by NSF-EPSCoR grant OSR 9255225 and the University of Nebraska-Lincoln Research Council. We thank the staff of the Organization for Tropical Studies for the opportunity to work at La Selva and for their hospitality. The staff of the Library of Natural Sounds, especially Andrea Priori, was helpful in finding and supplying recordings. Finally, we thank Donald E. Kroodsma, D. James Mountjoy, Hector Gomez de Silva, and an anonymous reviewer for extremely helpful comments on earlier versions of the manuscript.

\section{Literature Cited}

American Ornithologists' Union. 1998. Checklist of North American birds, 7th ed. American Ornithologists' Union, Washington, D.C.

BORROR, D. J., AND W. W. H. GUNN. 1965. Variation in White-throated Sparrow songs. Auk 82:26-47.

BROWN, R. N., AND R. E. LEMON. 1979. Structure and evolution of song form in the wrens Thryothorus sinaloa and T. felix. Behavioral Ecology and Sociobiology 5:111-131.

HARTSHORNE, C. 1956. The monotony-threshold in singing birds. Auk 73:176-192.

HeymanN, J., AND H. H. Bergmann. 1988. Incomplete song strophes in the Chaffinch Fringilla coelebs L.: General influences on a specific behavioural output. Bioacoustics 1:25-30.

Hill, B. G., AND M. R. LeIN. 1987. Function of frequency-shifted songs of Black-capped Chickadees. Condor 89:914-915.

Horn, A. G., M. L. Leonard, L. Ratcliffe, S. A. Shackleton, AND R. G. Weisman. 1992. Frequency variation in songs of Black-capped Chickadees (Parus atricapillus). Auk 109:847-852.

Howell, S. N. G., AND S. WebB. 1995. A guide to the birds of Mexico and northern Central America. Oxford University Press, New York.

KroodsmA, D. E. 1977. Correlates of song organization among North American wrens. American Naturalist 111:995-1008.

Kroodsma, D. E. 1980. Winter Wren singing behav- 
ior: A pinnacle of song complexity. Condor 82: 357-365.

Kroodsma, D. E., AND H. Momose. 1991. Songs of the Japanese population of the Winter Wren (Troglodytes troglodytes). Condor 93:424-432.

LAMBRECHTS, M. M. 1996. Organization of birdsong and constraints on performance. Pages 305-320 in Ecology and evolution of acoustic communication in birds (D. E. Kroodsma and E. H. Miller, Eds.). Cornell University Press, Ithaca, New York.

MORTON, E. S., AND K. YOUNG. 1986. A previously undescribed method of song matching in a species with a single song "type," the Kentucky Warbler (Oporornis formosus). Ethology 73:334342.

Nowicki, S., S. Peters, W. A. Searcy, And C. ClayTON. 1999. The development of within-song type variation in Song Sparrows. Animal Behaviour 57:1257-1264.

PoDOS, J. 1997. A performance constraint on the evo- lution of trilled vocalizations in a songbird family (Passeriformes: Emberizidae). Evolution 51: 537-551.

RICH, T. 1983. Incomplete songs and associated behavior of Sage Sparrows. Wilson Bulletin 95: 281-282.

Shackleton, S. A., L. Ratcliffe, A. G. Horn, And C. T. NAUGLer. 1991. Song repertoires of Harris' Sparrows (Zonotrichia querula). Canadian Journal of Zoology 69:1867-1874.

SLUD, P. 1958. Observations on the Nightingale Wren in Costa Rica. Condor 60:243-251.

StILES, F. G. 1983. The taxonomy of Microcerculus wrens (Troglodytidae) in Central America. Wilson Bulletin 95:169-183.

StILES, F. G. 1984. The songs of Microcerculus wrens in Costa Rica. Wilson Bulletin 96:99-103.

Received 16 August 1999, accepted 16 April 2000.

Associate Editor: D. E. Kroodsma 